\title{
Effects of dietary energy level on reproductive characteristics in male African giant rat Cricetomys gambianus
}

\section{Astride Martine Megnimeza Tsambou*, Augustave Kenfack, Bertin N. Vemo, Séverin Fonkem, Lavoisier Tadiesse Fonou, Constant Fopa Foda, Alexis Teguia}

\begin{abstract}
Department of Animal Sciences, Faculty of Agronomy and Agricultural Sciences, University of Dschang, Dschang,
\end{abstract} Cameroon

Received: 05 November 2019

Revised: 03 December 2019

Accepted: 11 December 2019

\section{*Correspondence:}

Dr. Astride M. Tsambou Megnimeza,

E-mail: astridetsambou@yahoo.ca

Copyright: () the author(s), publisher and licensee Medip Academy. This is an open-access article distributed under the terms of the Creative Commons Attribution Non-Commercial License, which permits unrestricted non-commercial use, distribution, and reproduction in any medium, provided the original work is properly cited.

\section{ABSTRACT}

Background: The study was conducted to assess the effects of the digestible dietary energy level on some reproductive characteristics in African giant rat.

Methods: Sixteen young males were randomly distributed into 4 groups of 4 animals each. To each group was attributed randomly one of the 4 dietary energy levels ( $3600 \mathrm{Kcal} / \mathrm{kg}, 3800 \mathrm{Kcal} / \mathrm{kg}, 4000 \mathrm{Kcal} / \mathrm{kg}$ or $4200 \mathrm{Kcal} / \mathrm{kg}$ ). The daily distribution of experimental diets last six months, ie ended when cricetoma were 8 months old. At the end of that period, all animals were sacrificed.

Results: Results showed an increase in testes weight with the augmentation of dietary digestible energy level $(0.79 \pm 0.13,0.88 \pm 0.17,1.02 \pm 0.28$ and $1.02 \pm 0.16$ respectively for $3600 \mathrm{Kcal} / \mathrm{kg}, 3800 \mathrm{Kcal} / \mathrm{kg}, 4000 \mathrm{Kcal} / \mathrm{kg}$ and $4200 \mathrm{Kcal} / \mathrm{kg}$ ). The serum testosterone level, the sperm mobility $(76.67,62,63$ and 57\%) and count per cauda epididymis $(18.25 \pm 3.75,16.38 \pm 4.19,10.83 \pm 2.02$ and $10.13 \pm 2.9)$ and per gram cauda epididymis $(39.09 \pm 11.82$, $27.01 \pm 4.23,15.41 \pm 3.31$ and $17.40 \pm 7.28)$ significantly $(\mathrm{p}<0.05)$ decreased with the increasing level of digestible energy in the feed.

Conclusions: The dietary digestible energy level that gave the higher reproductive performances in male African giant rat was $3600 \mathrm{Kcal} / \mathrm{kg} \mathrm{DM}$.

Keywords: African giant rat, Cauda epididymal sperm characteristics dietary energy level, Genital organs, Testosterone concentration

\section{INTRODUCTION}

Cricetoma is the biggest rat all over the world and is found in more than 29 countries. Because it is an appreciated source of meat for the population, it is the most hunted among the Sub-Saharan Africa games of small size. ${ }^{1,2}$ Its breeding would be a solution against overhunting. Unfortunately, in captivity, the African giant rat reproduces rarely, and if any, gives very low litters. Results of the studies conducted at the teaching and research farm of the University of Dschang, and those from private farms are perfect illustrations. Contrarily, when acquired from the wild life in pregnant status, the litter size can reach 7-8 at the kidding. The poor performances from the captivity are indicators of the lack of mastery of breeding techniques.

Cricetoma is an omnivorous and in the bush, feeds on various sources. ${ }^{2,3}$ It is possible that its nutritional requirements be not covered in captivity. 
Nutrition is one of the main factors involved in sexual development and reproductive function in mammals., ${ }^{4,5}$ Most studies indicate that a better nutrition at the beginning of life increases body and testes weights, blood testosterone level and epididymis reserve of sperm. ${ }^{6}$ In adult males for example, a high energy diet increases libido, seminiferous tubules and testes size hence, improves sperm production. ${ }^{7}$

Energy is the major element in feed responsible for the ingestion and utilization of different nutrients, and consequently animal productivity. Indeed, inadequate feed, particularly in energy in most breeding animals would negatively affect productive parameters as life weight and body fat which will have repercussions on cholesterol level and possibly on circulating $\mathrm{LH}$ and testosterone levels and semen quality in male. ${ }^{8-11}$ That is why 9 reported that energy excess or deficit in feed is detrimental to reproductive performances. Besides, 11 showed a decrease in sperm mobility and consequently fertility in male rats given high-fat diet. It is consequently necessary to know the optimal concentration of energy that allows the best productive performances in each animal species. To the best of our knowledge the energy needs of cricetoma are not known, hence the present study.

\section{METHODS}

\section{Animal material}

Sixteen young males' rats (Cricetomys gambianus) aged 2 months and averaging $293.41 \pm 19.21 \mathrm{~g}$, bred at the Teaching and Research Farm of the University of Dschang, Cameroon were used. They were housed individually in cages of $100 \mathrm{~cm}$ x $80 \mathrm{~cm}$ x $60 \mathrm{~cm}$ (length, width and height) under natural photoperiod.

\section{Inclusion criteria}

- All males in this study weighing between 285-295 g and the age of data collection of reproductive parameters were considered at 8 months old which represents in this study.

\section{Exclusion criteria}

- Animals with growth delay; animals with aggressive behaviour.

Table 1: Centesimal composition and bromatological characteristics of diets.

\begin{tabular}{|lllll|}
\hline \multirow{2}{*}{ Ingredients } & Centesimal composition & & \\
& D1 & D2 & D3 & D4 \\
\hline Corn & 52.00 & 60.50 & 60.00 & 60.00 \\
\hline Brewers chaffs & 15.00 & 08.00 & 11.50 & 09.50 \\
\hline Cottonseed meal & 08.00 & 05.00 & 02.00 & 00.00 \\
\hline Soya bean meal & 15.50 & 14.00 & 09.00 & 08.00 \\
\hline Fish flour & 2.00 & 04.00 & 05.00 & 06.00 \\
\hline Bone flour & 4.00 & 03.00 & 03.00 & 02.50 \\
\hline Palm oil & 2.00 & 03.00 & 05.50 & 08.00 \\
\hline Blood flour & 1.00 & 02.00 & 05.00 & 06.00 \\
\hline Salt & 0.50 & 0.50 & 0.50 & 0.50 \\
\hline Total & $\mathbf{1 0 0 . 0 0}$ & $\mathbf{1 0 0 . 0 0}$ & $\mathbf{1 0 0 . 0 0}$ & $\mathbf{1 0 0 . 0 0}$ \\
\hline Bromatological characteristics of diets & & & 19.10 & \\
\hline Crude Protein $(\%$ DM) & 19.30 & 19.30 & 4018.78 & 4208.41 \\
\hline Digestible energy (Kcal/kg DM) & 3620.00 & 3816.50 & & 19.16 \\
\hline
\end{tabular}

\section{Feeding}

The composition and chemical characteristics of experimental feeds are presented in Table 1.

\section{Experimental design}

Animals were randomly allocated to 4 groups, each corresponding to one the 4 dietary energy levels (3600 $\mathrm{Kcal} / \mathrm{kg}, 3800 \mathrm{Kcal} / \mathrm{kg}, 4000 \mathrm{Kcal} / \mathrm{kg}$ and $4200 \mathrm{Kcal} / \mathrm{kg}$ ). Each group was made up of 4 male cricetoma. The distribution of experimental feed last six month. At the end of that period, animals were sacrificed in order to evaluate the development of reproductive organs and epididymal sperm characteristics.

\section{Studied parameters and data collection}

Organ weight

At the end of treatment, the live weight was registered and animals were sacrificed. Reproductive organs (testes, epididymides, seminal vesicle, vas deferens and prostate) 
were removed, weighed and the average weight of each organ calculated as follow:

Organ weight $=\Sigma$ (individual organ weight/ animal life weight $\mathrm{x}$ 100)/number of individuals

\section{Histology of testes}

One testis of each animal was preserved for histological studies. The testis was fixed in $10 \%$ formol, washed with tap water, dehydrated gradually in alcohol solution $(80$, 90 and $100^{\circ}$ ), clarified in xylen baths, hardened in paraffin, sectioned and stained with haematoxylin and eosin. The sectioned tissues were observed and filmed under a light microscope at 400X magnification, using the camera of a microsystem Leica.

\section{Cauda epididymal sperm characteristics}

One of caudal epididymis was weighed and shredded in $10 \mathrm{ml}$ of $0.9 \% \mathrm{NaCl}$ solution, incubated at $37^{\circ} \mathrm{C}$.

\section{Mobility}

The mobility of sperm was appreciated by direct examination of the solution. Thus, $20 \mu \mathrm{l}$ of the previously prepared solution were placed on a slide, and then observed under a light microscope at magnification 400 . Sperm mobility was evaluated by attributing a score of 0 $5 .{ }^{12}$

\section{Concentration}

$0.1 \mathrm{ml}$ of the mother solution $(10 \mathrm{ml})$ was diluted with $2.4 \mathrm{ml}$ of formol (35\%) solution to kill and stabilize sperm during counting. A drop of the diluted solution was placed on the Thoma cell chamber and sperms counted under the light microscope at magnification of 400. To determine the sperm number in a tail of epididymis, the following formula was used

Number of sperm cells/tail $=(N \times 4 \times V \times D F \times$ 1000/0.1)/2

$\mathrm{N}$ : number of sperm in 4 big squares of the thoma cell. $\mathrm{V}$ : volume of stock solution $(10 \mathrm{ml})$,

DF: Dilution factor (25),

1000: convection factor of $\mathrm{mm}^{3}$ to $\mathrm{ml}$,

0.1 : volume of chamber $\left(\mathrm{mm}^{3}\right)$,

2: number of caudal epididymides shredded.

Sperm number was also expressed per gram of epididymis. Serum level of LH, FSH and testosterone. Serum was collected and used measure the concentration LH, FSH and testosterone in male using Omega Diagnostics (Scotland, United Kingdom).

\section{Ethic}

Animals were handled according to ethical guidelines of the cameroon national veterinary laboratory.

\section{Statistical analysis}

Results were expressed as mean \pm standard deviation. Differences between groups were assessed using one-way ANOVA followed by the Duncan's test at 5\% significance.

\section{RESULTS}

Table 2 summarize the variation of genital organs weights based on dietary digestive energy level. It indicates that testes, epididymis, vas deferens and accessory sex glands weight seemed to increase with the dietary digestible energy level, although not significantly $(\mathrm{p}>0.05)$.

Table 2: Effects of dietary energy level on sexual organ weight in cricetoma.

\begin{tabular}{|llllll|}
\hline \multirow{2}{*}{ Sexual organs (g/100 g bw) } & Dietary energy level (Kcal/kg DM) & & \\
& $\mathbf{3 6 0 0}$ & $\mathbf{3 8 0 0}$ & $\mathbf{4 0 0 0}$ & $\mathbf{4 2 0 0}$ & p-value \\
\hline Testes & $0.79 \pm 0.13$ & $0.88 \pm 0.17$ & $1.02 \pm 0.28$ & $1.02 \pm 0.16$ & 0.27 \\
\hline Caudal epididymides & $0.07 \pm 0.02$ & $0.09 \pm 0.02$ & $0.11 \pm 0.03$ & $0.10 \pm 0.02$ & 0.23 \\
\hline Epididymis head & $0.06 \pm 0.01$ & $0.07 \pm 0.02$ & $0.07 \pm 0.01$ & $0.07 \pm 0.02$ & 0.57 \\
\hline Epididymis & $0.13 \pm 0.02$ & $0.15 \pm 0.04$ & $0.18 \pm 0.04$ & $0.17 \pm 0.04$ & 0.33 \\
\hline Vas deferens & $0.03 \pm 0.01$ & $0.04 \pm 0.02$ & $0.03 \pm 0.00$ & $0.03 \pm 0.01$ & 0.68 \\
\hline Accessory sex glands & $0.52 \pm 0.18$ & $0.76 \pm 0,23$ & $0.89 \pm 0.34$ & $0.51 \pm 0.11$ & 0.37 \\
\hline
\end{tabular}

\section{Mobility and concentration of caudal epididymal spermatozoa}

The sperm mobility was significantly $(\mathrm{p}<0.05)$ higher in animals fed $3600 \mathrm{Kcal} / \mathrm{kg}$ DM compared to diet with of digestible energy $4200 \mathrm{Kcal} / \mathrm{kg} \mathrm{DM}$. However, no significant $(\mathrm{p}>0.05)$ difference was registered between diets at 3800 et $4000 \mathrm{Kcal} / \mathrm{kg} \mathrm{DM}$. Sperm count per caudal of epididymis was significantly $(\mathrm{p}<0.05)$ higher in animals fed $3600 \mathrm{Kcal} / \mathrm{kg}$ DM compared to diet with digestible energy $4200 \mathrm{Kcal} / \mathrm{kg}$ DM. Likewise, Sperm count per caudal of epididymis of animals receiving 3800 
$\mathrm{Kcal} / \mathrm{kg}$ DM was significantly $(\mathrm{p}<0.05)$ higher than that of animals fed $4000 \mathrm{Kcal} / \mathrm{kg}$ DM. Sperm count per gram of caudal epididymis decreased significantly $(\mathrm{p}<0.05)$ with increasing level of energy in feed (Table 3), the diet with $3800 \mathrm{Kcal} / \mathrm{kg}$ DM being comparable firstly with diet containing $3600 \mathrm{Kcal} / \mathrm{kg} \mathrm{DM}$ and secondly with diet at 4000 and $4200 \mathrm{Kcal} / \mathrm{kg} \mathrm{DM}$.

Table 3: Effects of dietary energy level on epididymal sperm characteristics in cricetoma.

\begin{tabular}{|llllll|}
\hline $\begin{array}{l}\text { Epididymal sperm } \\
\text { characteristics }\end{array}$ & Dietary energy level (Kcal/kgDM) & & \\
& $\mathbf{3 6 0 0}$ & $\mathbf{3 8 0 0}$ & $\mathbf{4 0 0 0}$ & $\mathbf{4 2 0 0}$ & p-value \\
\hline Motility $(\%)$ & $76.67 \pm 5.77^{\mathrm{a}}$ & $62.50 \pm 5.00^{\mathrm{ab}}$ & $63.33 \pm 15.28^{\mathrm{ab}}$ & $57.50 \pm 5.00^{\mathrm{b}}$ & 0.04 \\
\hline Number/tail $\left(\mathrm{x} 10^{7}\right)$ & $18.25 \pm 3.75^{\mathrm{a}}$ & $16.38 \pm 4.19^{\mathrm{ab}}$ & $10.83 \pm 2.02^{\mathrm{bc}}$ & $10.13 \pm 2.95^{\mathrm{c}}$ & 0.02 \\
\hline Number/g of tail $\left(\mathrm{x} 10^{7}\right)$ & $39.09 \pm 11.82^{\mathrm{a}}$ & $27.01 \pm 4.23^{\mathrm{ab}}$ & $15.41 \pm 3.31^{\mathrm{b}}$ & $17.40 \pm 7.28^{\mathrm{b}}$ & 0.01 \\
\hline
\end{tabular}

$\mathrm{a}, \mathrm{b}, \mathrm{c}$ : on the same line, values affected with the same letter do not differ significantly ( $\mathrm{p}>0.05)$.

\section{Serum level of LH, FSH and testosterone}

The serum levels of FSH (Figure 1) was significantly (P $<0.05)$ higher in animals fed $4000 \mathrm{Kcal} / \mathrm{kg}$ DM compared to other diets. That of LH (Figure 2) was significantly (P $<0.05)$ higher on rat fed on diet digestible energy 3800 $\mathrm{Kcal} / \mathrm{kg} \mathrm{DM}$. Concentration of testosterone in the serum (Figure 3) decreased significantly ( $\mathrm{p}<0.05)$ with increasing level of digestible energy in feed.

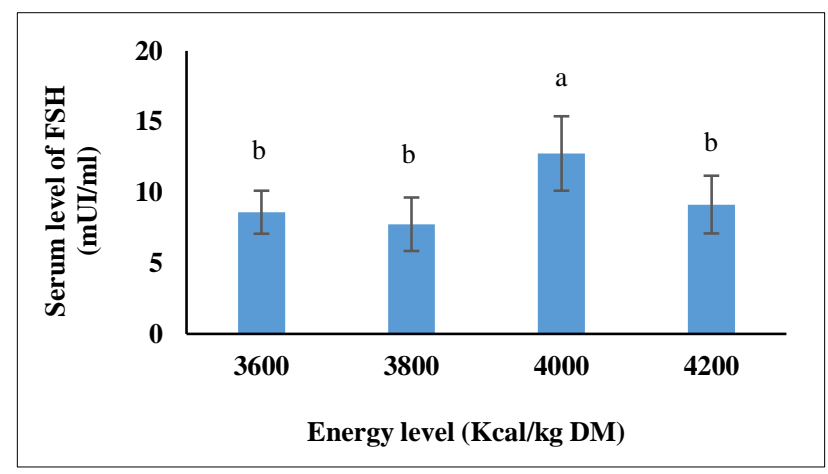

$a, b$ : on the same bar affected with the same letter do not differ significantly $(\mathrm{p}>0.05)$.

Figure 1: Effects of dietary energy level on serum level of FSH on male cricetoma.

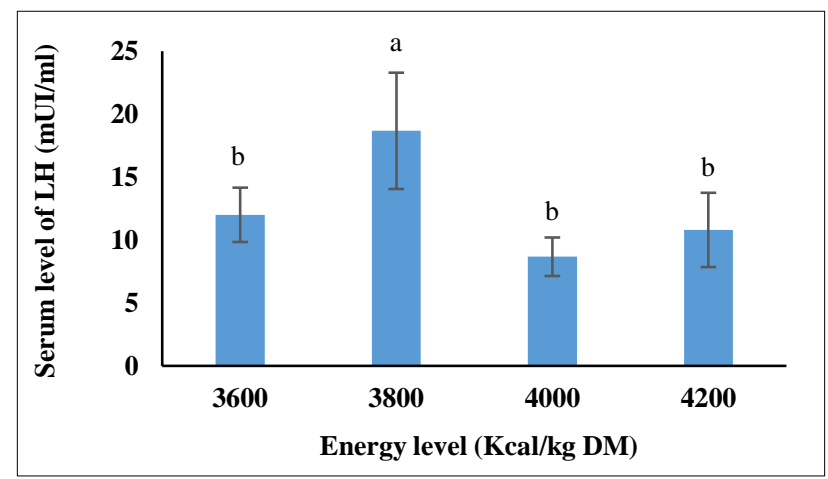

$a, b$ : on the same bars, values affected with the same letter do not differ significantly $(\mathrm{p}>0.05)$.

Figure 2: Effects of dietary energy level on serum level of $\mathrm{LH}$ on male cricetoma.

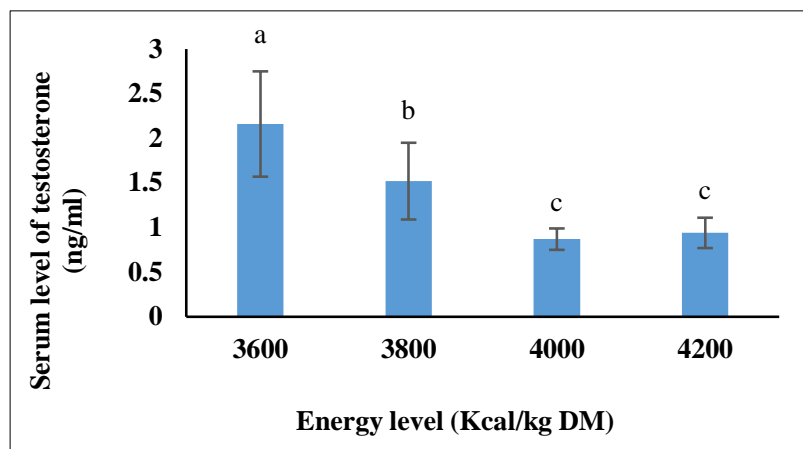

a, b, c: on the bar, values affected with the same letter do not differ significantly $(\mathrm{p}>0.05)$.

Figure 3: Effects of dietary energy level on serum level of testosterone on male cricetoma.
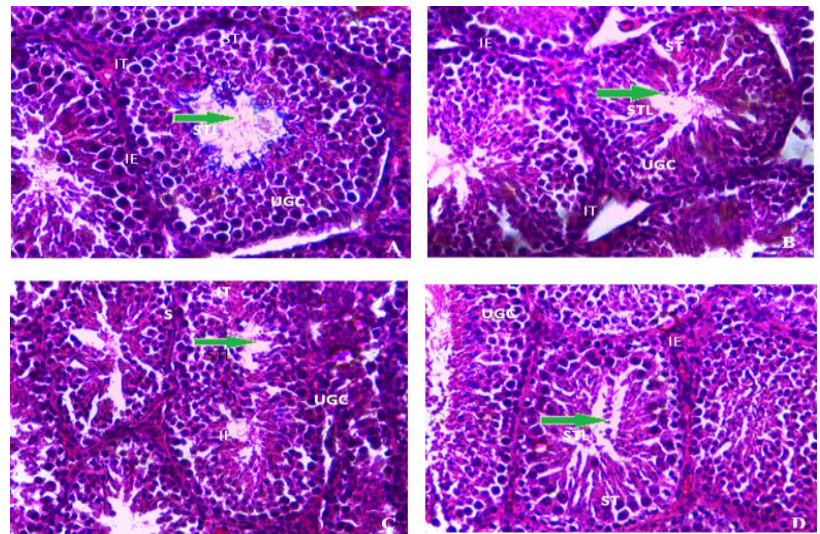

UGC: undifferenciated germ cell; IE: Interstitial espace; STL: Seminiferous tubules light; IT: Interstitial tissu; ST: seminiferous tubules. Plate A: $3600 \mathrm{Kcal} / \mathrm{kg}$ DM; Plate B: 3800 $\mathrm{Kcak} / \mathrm{kg} \mathrm{DM}$; Plate C: $4000 \mathrm{Kcal} / \mathrm{kg}$ DM; Plate D: 4200 $\mathrm{Kcal} / \mathrm{kg} \mathrm{DM}$.

Figure 4: Testes structure of cricetoma fed on digestible various dietary energy level $(\mathrm{HE} \times 400)$.

\section{Testes histology}

Whatever the dietary energy level, the microscopic observation of histological sections of testes (Figure 4) showed well organized, individualized and reduced 
interstitials space of seminiferous tubules. From the basal membrane to lumen were observed germinal cells at different stage of their development. The tubules lumen contains many matures sperm regardless of dietary energy level.

\section{DISCUSSION}

The reproductive function in animals is influenced by their nutritional requirements. ${ }^{5,7}$ In this study, the reproductive organs weight such as testes and epididymis were higher, although not significantly in animals fed higher level of energy $(4200 \mathrm{Kcal} / \mathrm{kg} \mathrm{DM})$. Similar results were obtained by in laboratory rat. ${ }^{13,14}$ The absence of the significant difference in testes weight is comforted by the structural integrity of those glands as shown by histological section under different dietary energy levels. Indeed, at the view of testes sections, none of the studied energy levels altered the structure of testes; their observation revealed none of the commonly apparent anomalies shown by altered testes, such as vacuolization of the seminiferous epithelium, depletion, massive presence of immature spermatozoa in the lumen of seminiferous tubules.

The similarity of epididymis, vas deferent and accessory glands weights seemed to be linked to the testis rather than the testosterone concentration that is known to be the hormone controlling their development. Indeed, contrarily to testis weight, testosterone concentration diminished with the increase of energy in the diet.

The low concentration of testosterone in rat fed 4000 $\mathrm{kcal} / \mathrm{kg}$. DM and above would be linked to blood $\mathrm{LH}$ concentration; this trend is normal because LH is the hormone stimulating its production.

Sperm concentration, mobility and morphology are first criteria used to evaluate male fertility. They are the first markers of testicular spermatogenesis and epididymis maturation. ${ }^{15,16}$ Generally, the higher the sperm count, the higher the mobility. Thus, the weak sperm mobility in cricetoma receiving the highest energy ration could be linked to their weak concentration in the cauda epididymis. Inturn the low sperm count would signify that the dietary energy level was excessive for an optimal production of spermatozoa, because a negative relationship is established between spermatogenesis and dietary energy level. ${ }^{10,17}$

\section{CONCLUSION}

At the end of this study, it can be admitted that the dietary digestible energy requirement that gave the best reproductive performances in male African giant rat was $3600 \mathrm{Kcal} / \mathrm{kg}$ DM. However, others study could be done on low energy level to more appreciate the real energy requirement in male African giant rat.
Funding: No funding sources

Conflict of interest: None declared

Ethical approval: The study was approved by the Institutional Ethics Committee

\section{REFERENCES}

1. Fonweban, Njwe. Feed utilization and live weight gain by the African giant rat (Cricetomys gambianus Waterhouse) at Dschang in Cameroun. Tropicultura. 1990;8(3):118-20.

2. Malekani. Guide technique de l'élevage $n^{\circ} 8$ sur les cricétomes. Gembloux N.E.D.I.M., FUSAGx. 2001;8.

3. Cooper RG. Care, husbandry and diseases of the African giant rat (Cricetomys gambianus). J. S. Afr Vet Assoc. 2008;79(2):62-6.

4. Balasubramanian P, Jagannathan L, Subramanian M, Gilbreath ET, Mohankumar PS, Mohankumar SJM. High-fat diet affects reproductive functions in female diet-induced obese and dietary resistant rats. J Neuroendocrinol. 2012;24(5):748-55.

5. Lie ME, Overgaard A, Mikkelsen JD. Effects of postnatal high-fatdiet expossure on puberty onset, estrous cycle regularity, and kiss peptin expression in female rats. Reprod Boil. 2013;13:298-308.

6. Dance A, Thundathil J, Wilde R, Blondin P, Kastelic J. Enhanced early-life nutrition promotes hormone production and reproductive development in Holstein bulls. J Dairy Sci. 2015;98(2):987-98.

7. Ros-Santaella JL, Kotrba R, Pintus E. High energy diet enhances spermatogenic function and increases sperm midpiee length in fallow deer (Dama dama) yearlings. R Soc Open Sci. 2019;6(6):1-13.

8. Ferguson. Nutrition and reproduction in dairy cows. Vet Clin North Amer Food Anim Pract. 1991;7(2):483-507.

9. Rekik A, Ben Gara A, Roussi H, Bakara FA, Grami A, Khaldi Z. Performances de croissance des agneaux de la race D'man dans les oasis Tunisiennes. Livestock Res Rural Develop. 2008;20(10):162.

10. Mu Y, Wen-jie, Yin T, Zhang Y, Li J, Yang J. Dietinduced obesity impairs spermatogenesis: a potential role for autophagy. Sci Rep. 2017;7:1-13.

11. Rosa JS, Omana J, Krishna PM, Shruthi I, Ramachandra SG, Thamaraiselvi K. Effect of feeding high fat diet on reproductive parameters in male mice. Indian J Anim Res. 2018:505-509.

12. Baril G, Chemineau P, Cognie Y, Guerin Y, Leboeuf $\mathrm{B}$, Orgeur $\mathrm{P}$, et al. Manuel de formation pour l'insémination artificielle chez les ovins et les caprins. In : Etude FAO, production et santé animale. Rome ITA: FAO. 1993;83:125.

13. Fungfuang W, Nakao N, Nakada T, Yokosuka M, Saito RT. Early onset of reproductive function in female rats treated with a high-fat diet. J Vet Sci. 2012;75(4):523-6.

14. Hussain MA, Abogresha NM, Hassan R, Tamany DA, Lotfy M. Effect of feeding a high-fat diet 
independently of caloric intake on reproductive function in diet-induced obese female rats. Arch Med Sci. 2016;12(4):906-14.

15. Jensen TK, Bonde JP, Joffe M. The influence of occupational exposure on male reproductive function. Occup Med. 2006;56:544-53.

16. Joshi SC, Sharma P. Male reproductive toxicity of organophosphorous compounds: a review. Toxicol. Environ Chem. 2011;93(7):1486-507.

17. Ibanez AC, Erthal PR, Ogo MF, Peres CNM, Vieira $\mathrm{RH}$, Conejo $\mathrm{C}$, et al. A high-fat diet during adolescence in male rats negatively programs reproductive and metabolic function which is partially ameliorated by exercise. Front Physiol. 2017;8:807.

Cite this article as: Tsambou AMM, Kenfack A, Vemo BN, Fonkem S, Fonou LT, Foda CF, et al. Effects of dietary energy level on reproductive characteristics in male African giant rat Cricetomys gambianus. Int J Reprod Contracept Obstet Gynecol 2020;9:468-73. 